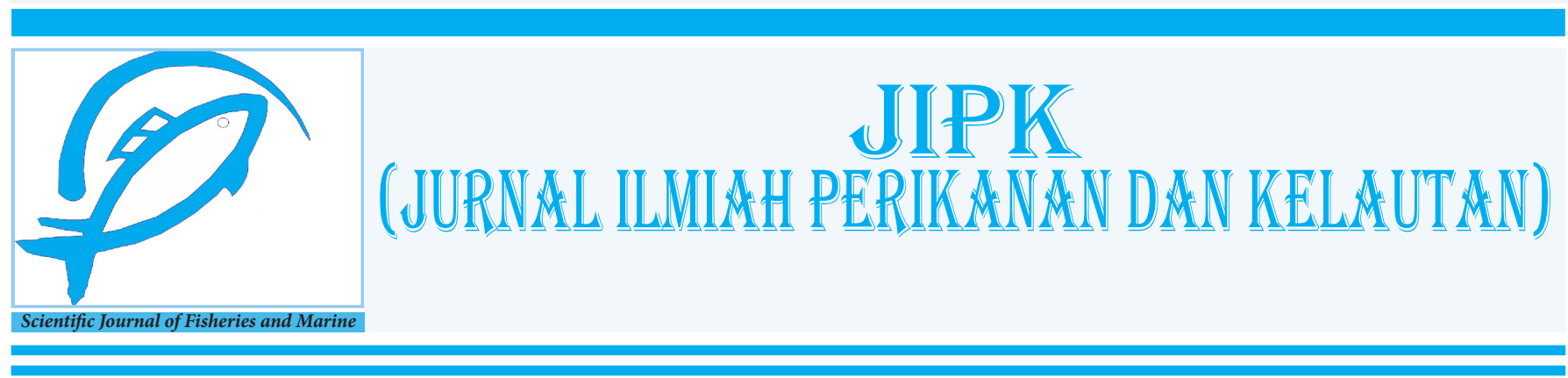

Research Article

\title{
Spawning Potential Ratio (SPR) Approach as a Management Measure of Skipjack Sustainability Record from Cilacap Fishing Port, Central Java, Indonesia
}

\author{
Yonvitner $^{1,2 *}$ (D), Mennofatria Boer ${ }^{1}$, and Rahmat Kurnia ${ }^{1}$ \\ ${ }^{1}$ Department of Aquatic Resource Management, Faculty of Fisheries and Marine Science, IPB University, Bogor, West Java. Indonesia \\ ${ }^{2}$ Centre for Coastal and Marine Resources Studies, IPB University, Bogor, West Java. Indonesia
}

\section{OPEN

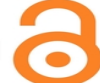 \\ ACCESS}

\section{$\underline{\text { ARTICLE INFO }}$}

Received: January 01, 2021

Accepted: July 01, 2021

Published: September 28, 2021

*) Corresponding author:

E-mail:yonvitr@yahoo.com

Keywords:

Length

Skipjack

Spawning Potential Ratio Management Measure

Sustainability

This is an open access article under the CC BY-NC-SA license (https://creativecommons.org/ licenses/by-nc-sa/4.0/)

\begin{abstract}
When data is limited, management measurement from fisheries makes it possible to use natural history data to analyze the potential spawning ratio (SPR). This research aimed to determine skipjack fish management measure from the Indian Ocean landed at Cilacap Fishing Port through the SPR approach. The study was conducted in December 2014 to March 2015 using length and reproduction data. The analysis consisted of the size structure, growth rate, and asymptotic length that were analyzed using FISAT II program and length at fifty percent maturity (Lm50). The SPR analysis used SPR software from the application in http://barefootecologist.com.au/ lbspr. The size distributions of skipjack obtained were a length of 220$790 \mathrm{~mm}$ and an average dominant length of $311-371 \mathrm{~mm}$. The asymptotic length obtained was $831.57 \mathrm{~mm}$, with growth rate and natural mortality of 1.1 and 1.44 per year respectively. The population proportion of $50 \%$ reaching gonad maturity (Lm50) was found at a length of $494.75 \mathrm{~mm}$ and $(\mathrm{Lm} 95=522.39 \mathrm{~mm})$ with an $\mathrm{M} / \mathrm{k}$ ratio of 1.309 . The length selectivity level was caught 50\% (SL50 = 317.36 mm) and 95\% (SL95 = 373.1 mm). The spawning potential ratio (SPR) ranged from 2-4 with an average of 4\% during observation. The SPR potential, which is lower from the standardized threshold of $40 \%$, indicates many young fish populations are caught, and the potential for overfishing is high, high risk, and low sustainability.
\end{abstract}

Cite this as: Yonvitner, Boer, M., \& Kurnia. R. (2021). Spawning Potential Ratio (SPR) Approach as a Management Measure of Skipjack Sustainability Record from Cilacap Fishing Port, Central Java, Indonesia. Jurnal Ilmiah Perikanan dan Kelautan, 13(2):199-207. http://doi.org/10.20473/jipk.v13i2.24926 


\section{Introduction}

The main problems of skipjack fisheries management that found in the Indian Ocean are limited information on the fishing ground (Angraeni et al., 2014), dynamics of fishing ground (Tangke and Deni, 2013), quality of fish (Angela et al., 2015), the seasonal fishing change (Kekenusa et al., 2012), and the timing of catch activity in FADs (Winarso, 2005). Syukhriani et al. (2018) found in the Bengkulu landing site is fishing port facilities standard that relates with Lowing $\mathrm{T}$ (2020) which is supply chains and cold chain systems (Lailossa, 2017) and marketing margins (Mamarodia et al., 2019). Problems related to natural history and population dynamics include the suitability of predictions for stock food availability (Kekenusa, 2006), spawning season (Jatmiko et al. 2015), reproductive size and length (Satria and Kurnia, 2017), and size structure inhabiting fish aggregating device (FADs) (Nurdin and Panggabean, 2018).

Skipjack fish is a large pelagic fish with high economic value and is mostly caught from the Indian Ocean. One landing port for fish caught by fishermen from the Indian Ocean is the Cilacap Fishing Port (CFP), Central Java. Skipjack fish in the Indian Ocean are generally caught with purse seine, longline, handline (Nurdin and Nugraha, 2017), and dominant in FAD locations. According to Wujdi et al. (2017), the skipjack fishery in WPP 573 is a population unit that interacts from west to east. Skipjack fisheries management is also faced with problems including invalid and unreliable data, and untraceable fishing grounds. The skipjack fisheries management practice was also classified as poor data for the management. Thus, the implementation of sustainable fisheries management from skipjack can still be approached by poor data analysis models.

A common approach to analyze poor data is based on biological data, including length and reproduction data. Length data can be used to predict growth, recruitment, and the first measure caught. Reproduction data can be used to determine the proportion of fish reaching gonad maturity, size at first maturity of gonads, and the ratio of potential spawning and recruiting. This research aimed to estimate the spawning potential ratio of skipjack from length-based data analysis. Jatmiko et al. (2015) researched skipjack tuna's reproductive aspects in South Java at 8 locations with various maturity trends. They found that the proportion of mature gonads reached $64 \%$ (TKG III and IV) and reached $429 \mathrm{~mm}$ for the first time. Kurniawan (2015) recorded skipjack fish production throughout the year with the peak production in August-October. The reproduction season was predicted to occur in April and November by
Restiangsih and Amri (2019).

Information on the spawning season, the length of the first maturity of the gonads is necessary to ascertain potential recruits and potential spawning ratio. According to Hordyk et al. (2015b), a large fish spawning possible ratio of $40 \%$ will provide a good availability of new populations (recruit). However, if recruits' potential is low, it is assumed that the stock's sustainability will also falter. Indication of the proportion of mature gonads, length at first caught, length at maturity, and spawning potential ratio is very important in managing skipjack fish populations.

In the reproduction aspect, most of the studies conducted are related to sex ratio, reproductive index, and length at maturity (Soares et al., 2019) in the southwest Atlantic, ganado somatic index, seasonal variation in Westen Indian Ocean (Stéquert et al., 2001), spawning frequency in South Pacific, Spawning activity, and batch fecundity (Grande et al., 2010), reproductive timing and capacity (Grande et al., 2014). The relation with the spawning potential ratio (SPR) for skipjack has been carried out in eastern Indonesian waters (Satria and Sadiyah, 2017), the target reference point in WCPO, and spawning potential ratio based on length in Tanzania (Kibona and Jónasson, 2019). Mueni et al. (2019) analyzed species composition, abundance, and SPR in Kenyan waters for tunas groups, including skipjack.

Spawning potential ratio (SPR) as an indicator of the reproductive and recruitment capabilities of skipjack fish from the Indian Ocean based on length data is lacking and has not been studied in the previous research. Different species that have interactions with the Indian Ocean are the SPR of Priachanthus tayenus (Yonvitner et al., 2021a), Nemipterus japonicus (Yonvitner et al., 2021b), and snapper and grouper in Saleh Bay (Efendi et al., 2020). The information from the length-based SPR for skipjack fish from the catch of fishers in the Indian Ocean on landing in Cilacap is the novelty of this study. This study aims to determine the ratio of the spawning potential and any natural history parameter of skipjack caught from the Indian Ocean to determine reproductive potential and recruitment.

\section{Materials and Methods}

\subsection{Research Area}

This research was conducted for four months from December 2014-March 2015, located at the Cilacap Fishing Port, Central Java. Cilacap fishing port lies at south of Central Java Province and borders of the Indian Ocean (Figure 1). The skipjack species landed is dominantly caught by fisherman from the Indian Ocean. 


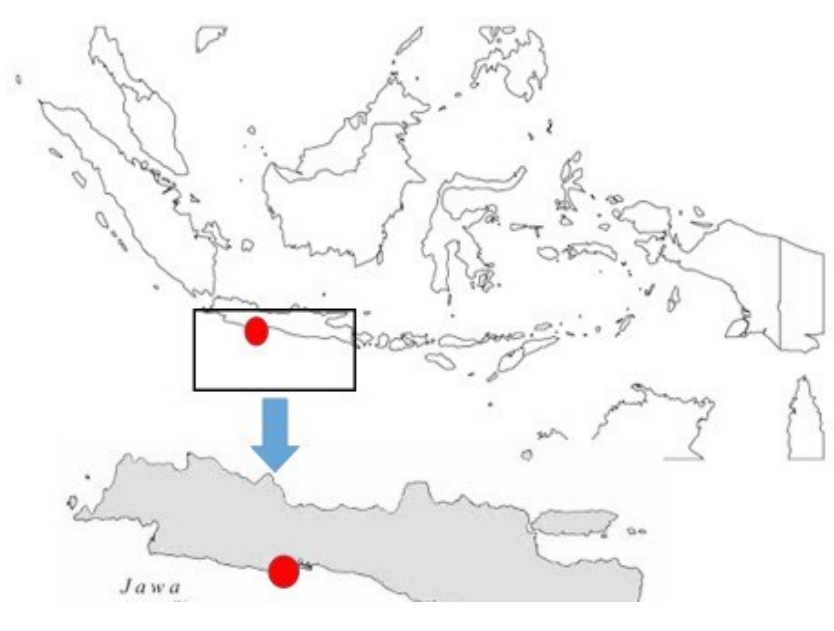

Figure 1. Research area in Cilacap fishing port, Central Java

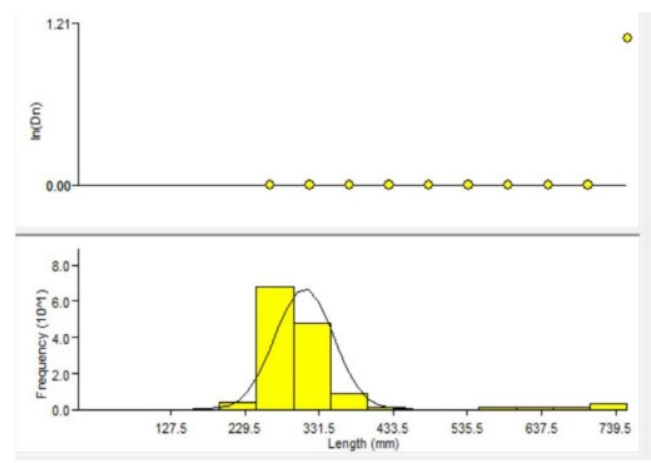

Desember

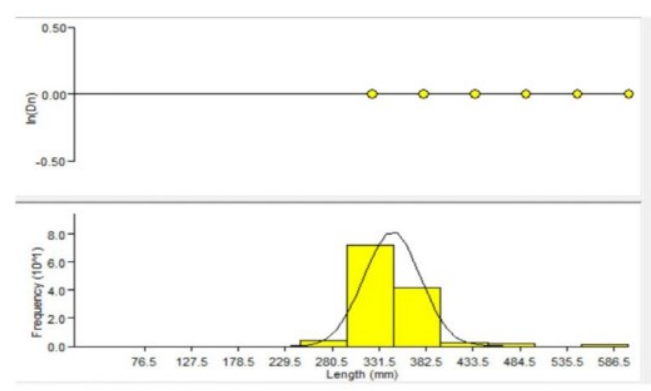

Februari nad maturity level. The ovaries were collected to evaluate mature eggs remnants and were also assigned to a gross stage of morphological gonad development. The fish's size for each stage of gonad maturity recorded is essential for determining the first size to reach gonad maturity. According to the gonad maturity classification, the determination of the TKG of skipjack fish was carried out morphologically using the classification of morphological differences (Orange, 1961).

\subsection{Biology Parameter and SPR}

The biology parameter is fundamental to fisheries biology data. Such a basic is the essence for sufficient management, such as the growth rate, natural and fishing mortality, maturity stage, and size of skipjack stocks (Hommik et al., 2020). The skipjack biology parameters such as natural mortality $(\mathrm{M})$, growth rate $(\mathrm{k})$, length at $50 \%$ population mature $\left(\mathrm{L}_{\mathrm{m}} 50\right)$, and asymptotic
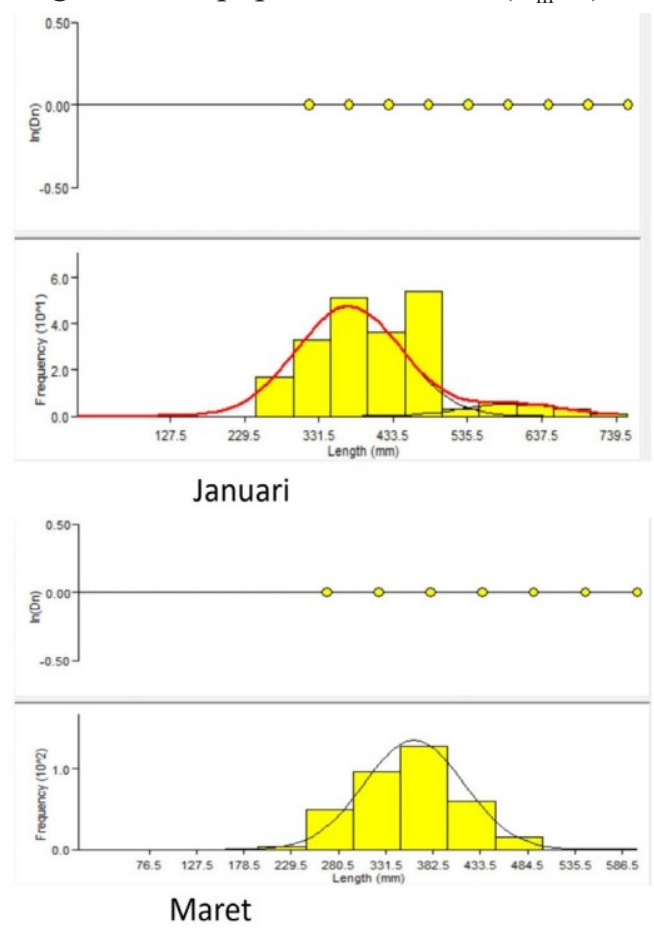

Figure 2. Length frequency distribution and cohort of skipjack ( $A=$ December 2014; $B=J a n u a r y ~ 2015 ; C=F e-$ bruary 2015 and $\mathrm{D}=$ March 2015)

\subsection{Size and Maturity}

The skipjack samples for length and reproduction measurements were taken randomly from the fisherman's catch. Skipjack tuna were chosen to be measured all length sizes from small to large. The total length from the fish mouth to the end of the tail was measured using a rules (accuracy $1 \mathrm{~cm}$ ). The length data were collected, listed in the datasheet, where overall 822 fish were successfully measured during the study.

Samples that have been measured then performed the surgery. The gonads of the female skipjack tuna found were taken and preserved to analyze the go- length $\left(\mathrm{L}_{\infty}\right)$ are relevant as determining the natural history information of a skipjack. The von Bertalanffy plot was generally used to identify fish growth rate, which is given as formula $\mathrm{L}_{\mathrm{t}}=\mathrm{L}_{\infty}\left(1-^{-\mathrm{k}\left(\mathrm{e}^{-t}\right)}\right)$ (Leland et al., 2015). Notation $L_{t}$ is the length at age $t$, asymptotic length $\left(\mathrm{L}_{\infty}\right)$ is the theoretical length at infinite phase. The growth parameter $(\mathrm{k})$ is the growth rate coefficient, and $t_{0}$ is the theoretical age when distance equals zero.

The biology parameters of skipjack analysis, which are growth rate $(\mathrm{k})$, asymptotic length $(\mathrm{L} \infty)$, and natural mortality $(\mathrm{M})$, are conducted with length-based approach using the FISAT Program. The length data in 
a sample primarily determine the SPR value based on length data derived by the model. Using barefootecology toolbox originated in Jeremy Prince's work in the early 2000s through open-source link http://barefootecologist.com.au/lbspr. (Prince et al., 2015).

\section{Results and Discussion}

\subsection{Length Structure}

The length-frequency distribution of skipjack from December 2014 to March 2015 generally found one group (cohort) (Figure 2). In December 2014, the average length of the caught skipjack was $311 \pm 39.80$ $\mathrm{mm}$. In January, the average lengths caught were 372.72 $\pm 71.71 \mathrm{~mm}$ and $601.77 \pm 69.9 \mathrm{~mm}$. In February, the caught skipjack length was $345.75 \pm 30.67 \mathrm{~mm}$, and in March, the length of the catch was $362.13 \pm 53.13 \mathrm{~mm}$.

Based on the results, it is seen that there is an increase in the average length size. In January, there was an increase in the size diversity of fish caught with two age groups. However, the dominant length of fish caught was in the range of $311-372 \mathrm{~mm}$, showed the average size was small and tended to be uniform. This condition can be presumed due to the factor of fish grouping (schooling) and fishing grounds at FAD locations (FAD/ fish aggregating device).

\subsection{Growth and Mortality}

Fish growth is an important indicator to assess the potential for recruitment and recovery of fish population biomass. Based on the analysis of the frequency distribution of the skipjack length, the asymptotic length was $831.5 \mathrm{~mm}$ and the length growth rate was 1.1 per year (Figure 3).

The skipjack length growth rate of 1.1 per year is relatively high and potential to increase resilience and also prevent fishing capture. However, fishing activity occurs continuously, and the high-intensity level also increases the fishing rate.

\subsection{Maturity and Selectivity}

Maturity is one of the phases that determine reproductive success, recruitment, and stock resilience. Based on the gonad maturity level analysis for the total population of skipjack fish, it reached the proportion of 50\% mature gonads (Lm50) at $494.75 \mathrm{~mm}$ size, and the proportion $95 \%$ reached gonad maturity $(\mathrm{Lm} 95)$ at $522.39 \mathrm{~mm}$ size (Figure 4).

The size selectivity, where a $50 \%$ skipjack caught in 2014 at a size of $280.5 \mathrm{~mm}$ and a $95 \%$ chance at $306.63 \mathrm{~mm}$. The selectivity of catch size length 2015 , where $50 \%$ chance of being caught at length $334.5 \mathrm{~mm}$, and $95 \%$ chance at length $394.93 \mathrm{~mm}$. Overall, the catch probability's selectivity was $50 \%$ at $317.36 \mathrm{~mm}$ in length and $95 \%$ for the $373.1 \mathrm{~mm}$ length. The ratio of fishing mortality to natural mortality $(\mathrm{F} / \mathrm{M})$ is also classified as high, between 3.25-3.93, with an average F/M of 2.8. The $\mathrm{M} / \mathrm{k}$ ratio of the skipjack is 1.30 indicates the presence of small fish dominance (Hordyk et al., $2015 \mathrm{a})$. The ratio $(\mathrm{M} / \mathrm{k})$ of 1.5 assumes that the waters are dominated by small fish that shown as overfishing. It means the fisheries stock status as potential high risk of fish sustainability in the sea is relatively low.

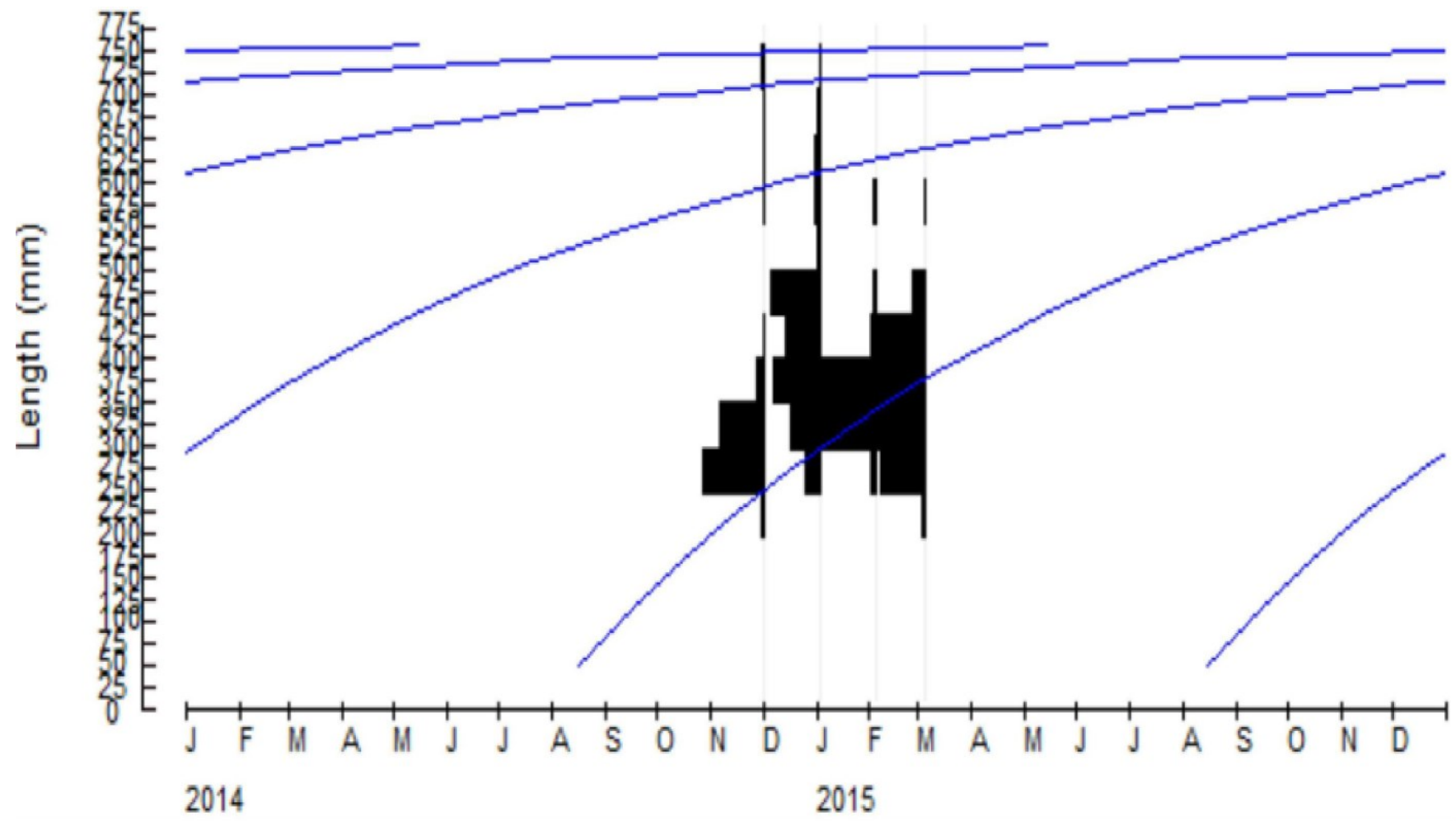

Figure 3. Growth rate model of skipjack obtained from FISAT II software with the Von Bertalanffy plot 
JIPK. Volume 13 No 2. November 2021 / Spawning Potential Ratio (SPR) Approach as a Management.........
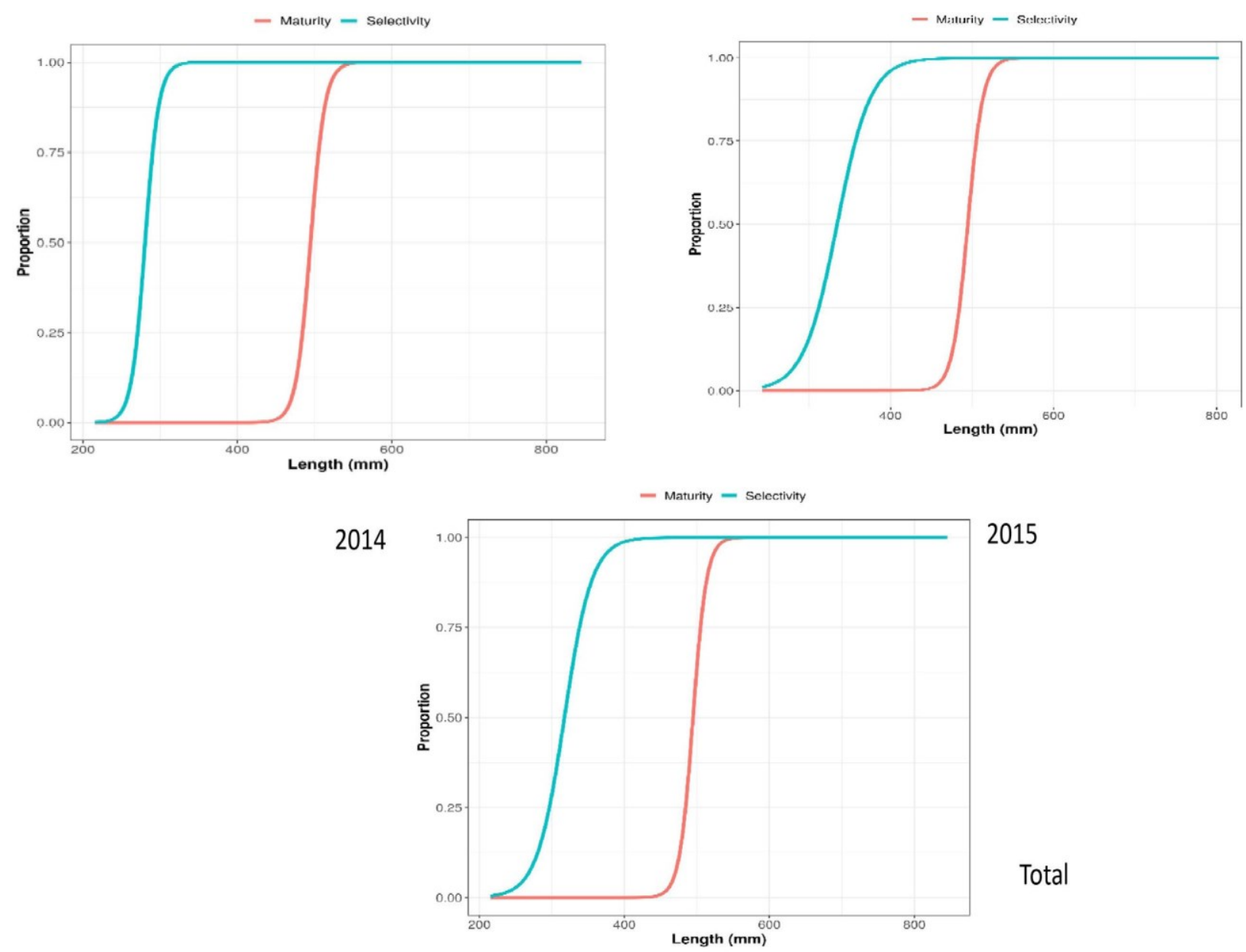

2015

Total

Figure 4. The comparison between proportion of skipjack at fifty percent maturity (Lm50) and selectivity $(\mathrm{A}=$ 2014; $\mathrm{B}=2015$; and $\mathrm{C}=$ total data)

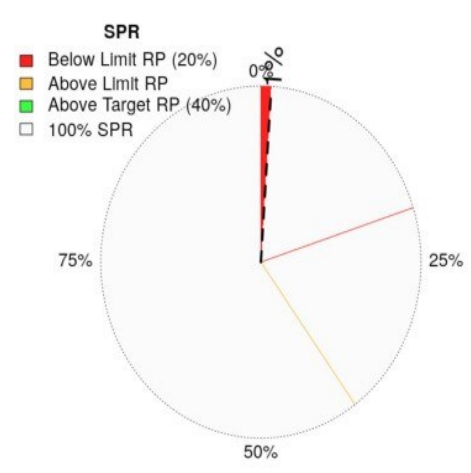

2014

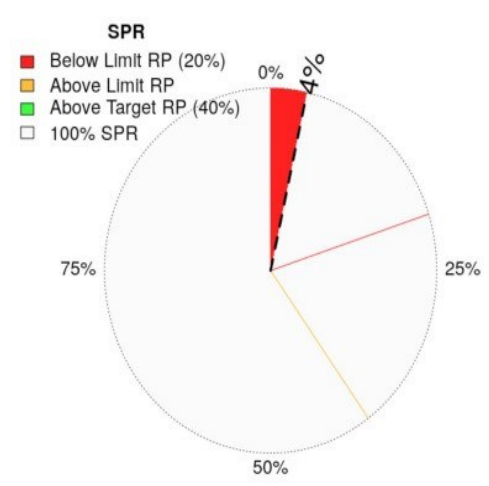

2015

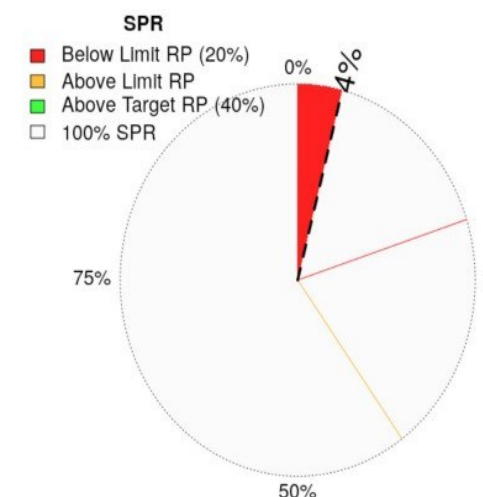

Total

Figure 5. Estimation of skipjack SPR (spawning potential ratio) $(A=2014),(B=2015)$ and $(C=$ aggregate from 2014 and 2015). 


\subsection{Discussion}

According to Nurdin and Panggabean (2018), skipjack fish in Pelabuhan Ratu have a length between 240-600 mm. Meanwhile, Parigi skipjack, East Java, measuring from 320-360 mm (Nurdin and Yusfiandayani, 2012), is relatively the same as the catch in Cilacap. Gunung Kidul fishermen's catch ranges from 200-680 $\mathrm{mm}$ with a dominant catch size of 300-340 mm (Anggraeni et al., 2015). Then Restiangsih and Amri (2019) got the first size caught in Flores at a size of $488 \mathrm{~mm}$ and reached the first maturity of gonads at $411 \mathrm{~mm}$.

Zedta et al. (2018) noted that the asymptotic length in WPP 573 was $672 \mathrm{~mm}$ with a $0.27 /$ year growth rate. Rochman et al. (2015), from data in 2012, found a growth rate of 1.1 per year, an asymptotic length of $808.5 \mathrm{~mm}$, and natural mortality of 1.44 per year. The same growth rate, asymptotic length, and natural mortality decreased. However, Rochman et al. (2015) from the 2012 data recorded a fishing mortality rate of 1.55 per year and this was also classified as high. Skipjack landed at Gunung Kidul fishing port first reached gonad maturity at an estimated $405 \mathrm{~mm}$ (Anggraeni et al., 2015).

Zedta et al. (2018) estimated that the mortality rate due to fishing is 0.43 / year and an F/M ratio of 0.7288 which meant that the natural mortality rate is still high. However, the El Nino phenomenon that occurred often affects increasing skipjack production in June-September 2015, increasing the skipjack tuna population (Anggraeni et al., 2017).

The limit reference point (LRP) of spawning potential ratio (SPR) is $40 \%$ (Hordyk et al., 2015b). SPR lower than $40 \%$ means low recruitment potential and low stock resilience. SPR value higher than $40 \%$ indicates potential for recruitment, high stock resilience, and high sustainability potential. The length data analyzed during the observation time in 2014 and 2015 was below the SPR limit reference point of $40 \%$ (Figure 5). The potential SPR in 2014 is estimated to be between $0-2 \%$ with an annual average of $1 \%$. Data for 2015 , the potential SPR is estimated to range from $2-5 \%$ with an annual average of $4 \%$. The aggregate data analysis obtained an SPR forecast between 3-5\% with an average of $4 \%$ per year.

The high fishing mortality rate is one of the causes of the low water stock and the potential for population reliance. Although fish are able to grow rapidly, the estimated adult population may decline further due to continuous fishing. The decreasing of asymptotic length is an indication that the stock has decreased in size and the potential for overfishing. Satria and Sadiyah (2017) found that the spawning potential ratio of skipjack in FMAs 713-715 is less than 20\% which meant recruitment overfishing. Estimating length-based potential spawning ratios can minimize bias to quantify stock estimates (Pons et al., 2019) so it can be recommended to be used.

\section{Conclusion}

When the size of the asymptotic length decreased, the mortality rate was increased. The increasing selectivity describes the ease of fishing. The ease of catching is also influenced by the behavior of fish that form schooling. As an impact, the catch ratio of skipjack fish is very high, which can be seen from the low level of selectivity (SL95) compared to the size of the fish that have reached maturity. This situation is then seen from the low spawning potential ratio (SPR) with less than the limit reference point is $4 \%$. This fact indicates low recruitment and high-risk level due to the high pressure on the Indian Ocean skipjack population. It means the sustainability potency of skipjack stock in the Indian Ocean is relatively low and potential high risk and overfishing.

\section{Acknowledgment}

The authors would like to thank the research team at IPB University (Aisyah Intan Widya Satria, Siti Nurkhotimi, Surya Gentha Akmal) who participated in the research and fieldwork. Special thanks to landing first port authority and local fisherman Mr. Mulyono as assistance during data collection in the field.

\section{Authors' Contributions}

All authors have contributed to the final manuscript. The contribution of each author as follow, Yonvitner; contributed to coordinating projects, collected and compiled sampling plans, processed data analysis, wrote reports, wrote journals, and being responsible for data analysis. Mennofatria Boer; contributed on planning and monitoring sampling, analyzed data obtained, interpreted data, compiled journals, and supervised students. Rahmat Kurnia; contributed on planning and monitoring sampling, analyze data obtained, and pie chart or bar performance, interpreted data, wrote journals, and supervised students.

\section{Conflict of Interest}

This statement is to certify that all authors have seen and approved the manuscript being submitted. We warrant that the article is the Authors' original work and participate in research work and writing paper. We warrant that the article has not received prior publication and is not under consideration for publication elsewhere. We have no conflicts of interest to disclose. On behalf of all Co-Authors, the corresponding Author shall bear full responsibility for the submission. We attest that all authors listed on the title page have contributed signifi- 
cantly to the project, have read the manuscript, attest to the validity and legitimacy of the data and its interpretation, data collecting, and analysis, and agree to its submission to this journal.

All authors agree that the author list is correct in its content and order and that no modification to the author list can be made without the formal approval of the Editor-in-Chief, and all authors accept that the Editor-in-Chief's decisions over acceptance or rejection or in the event of any breach of the Principles of Ethical Publishing in this journal being discovered of retraction are final.

\section{Funding Information}

This study was financially supported by Grant/ Award Number 4153/IT3.L1.PN/2015 provided by the government of the Republic of Indonesia through the Ministry of Research and Technology and Higher Education. This support particularly aims to project activity in field and laboratory, seminar, and publication.

\section{References}

Angela, G. C., Mentang, F., \& Sanger, G. (2015). Kajian mutu ikan cakalang (Katsuwonus pelamis, L.) asap dari tempat pengasapan desa girian atas yang dikemas vakum dan non vakum selama penyimpanan dingin. Media Teknologi Hasil Perikanan, 3(2).

Angraeni, A., Rezkyanti, N. I., Safruddin, S., \& Zainuddin, M. (2014). Analisis Spasial dan Temporal Hasil Tangkapan Ikan Cakalang (Katsuwonus pelamis) dan thermal front pada musim peralihan di perairan Teluk Bone. Jurnal IPTEKS Pemanfaatan Sumberdaya Perikanan, 1(1).

Anggraeni, R., Solichin, A., \& Saputra, S. W. (2015). Beberapa aspek biologi ikan cakalang (Katsuwonus pelamis) dalam kaitannya untuk pengelolaan perikanan di PPP Sadeng Kabupaten Gunungkidul Yogyakarta. Management of Aquatic Resources Journal, 4(3):230-239.

Anggraeni, R. I., Widagdo, S., \& Rahyono, R. (2017, Juli). Hubungan upwelling dengan jumlah tangkapan ikan cakalang pada musim timur di Perairan Tamperan, Pacitan. Paper presented at the Seminar Nasional Kelautan XII: Inovasi Hasil Riset dan Teknologi dalam Rangka Penguatan Kemandirian Pengelolaan Sumber Daya Laut dan Pesisir, University of Hang Tuah, Indonesia.

Efendi, D. S., Adrianto, L., Wardiatno, Y., \& Agustina, S. (2020). The performance of stock indicators of grouper (Serranidae) and snapper (Lutjani- dae) fisheries in Saleh Bay, Indonesia. Aquaculture, Aquarium, Conservation \& Legislation, 13(5):2431-2444.

Grande, M., Murua, H., Zudaire, I., \& Korta, M. (2010). Spawning activity and batch fecundity of skipjack, Katsuwonus pelamis, in the Western Indian Ocean. Paper presented at Proceedings of the 10th Meeting of the Working Party on Tropical Tuna, Indian Ocean Tuna Commission, IOTC-2010WPTT-47.

Grande, M., Murua, H., Zudaire, I., Goni, N., \& Bodin, N. (2014). Reproductive timing and reproductive capacity of the Skipjack Tuna (Katsuwonus pelamis) in the western Indian Ocean. Fisheries Research, 156:14-22.

Hordyk, A. R., Loneragan, N. R., \& Prince, J. D. (2015a). An evaluation of an iterative harvest strategy for data-poor fisheries using the lengthbased spawning potential ratio assessment methodology. Fisheries Research, 171:20-32.

Hordyk, A., Ono, K., Valencia, S., Loneragan, N., \& Prince, J. (2015b). A novel length-based empirical estimation method of spawning potential ratio (SPR) and tests of its performance for small-scale, data-poor fisheries. ICES Journal of Marine Science, 72(1):217-231.

Hommik, K., Fitzgerald, C. J., Kelly, F., \& Shephard, S. (2020). Dome-shaped selectivity in LB-SPR: Length-Based assessment of data-limited inland fish stocks sampled with gillnets. Fisheries Research, 229:105574.

Jatmiko, I., Hartaty, H., \& Bahtiar, A. (2015). Biologi reproduksi ikan cakalang (Katsuwonus pelamis) di Samudera Hindia bagian Timur. BAWAL Widya Riset Perikanan Tangkap, 7(2):87-94.

Kekenusa, J. S., Watung, V. N., \& Hatidja, D. (2012). Analisis penentuan musim penangkapan ikan cakalang (Katsuwonus pelamis) di Perairan Manado Sulawesi Utara. Jurnal Ilmiah Sains, 12(2):112-119.

Kekenusa J. S. (2006). Pemodelan Hasil Tangkapan dan Evaluasi Model Produksi Surplus Ikan Cakalang yang tertangkap di Perairan sekitar Bitung Provinsi Sulawesi Utara. Doctoral dissertation. Surabaya: Universitas Airlangga).

Kibona, O. M., \& Jónasson, J. P. (2019). Application of Length-Based Spawning Potential Ratio Method and Analysis of the Structure of the Electronic Catch Assessment Survey in Marine Waters of Mainland, Tanzania. Iceland: UNESCO 


\section{GRÓ-Fisheries Training Programme.}

Kurniawan, W. (2015). Musim penangkapan ikan cakalang di perairan selatan Jawa Barat dan kaitannya dengan parameter oceanografi. Oceana, XL(4):53-60.

Lailossa, G. W. (2017). Model Cold Chain System Untuk Peningkatan Kualitas Ekspor Tuna, Tongkol, Cakalang (TTC). Doctoral dissertation. Surabaya: Institut Teknologi Sepuluh Nopember.

Leland, J. C., Bucher, D. J., \& Coughran, J. (2015). Direct age determination of a subtropical freshwater crayfish (redclaw, Cherax quadricarinatus) using ossicular growth marks. PloS one, 10(8):e0134966.

Lowing, T. (2020). Analisis Manajemen Rantai Pasok Ikan Cakalang Di Tempat Pelelangan Ikan Tumumpa Kota Manado. Jurnal EMBA: Jurnal Riset Ekonomi, Manajemen, Bisnis dan Akuntansi, 8(1).

Mueni, E., Ndegwa, S., Magak, C., Omukoto, J., Okemwa, G., Imam, R., Wachira, K., Mwasi, L., Kapombe, L., Bandari, S., \& Kimakwa, E. (2019). Species composition, abundance and preliminary spawning potential Ratio (SPR) assessment for tuna and tuna like species: Some results from application of mobile phone Catch Assessment Survey, Kenya. IOTC-2019-WPDCS15-23.

Mamarodia, A. A., Ngangi, C., \& Manuhutu, E. A. (2019). Analisis Margin Pemasaran Abon Ikan Cakalang Ud. Trikora Manado. Doctoral dissertation. Manado: Universitas Katolik De La Salle.

Nurdin, E., \& Yusfiandayani, R. (2012). Struktur ukuran, hubungan panjang-bobot dan faktor kondisi ikan tuna di Perairan Prigi, Jawa Timur. $B A W A L$ Widya Riset Perikanan Tangkap, 4(2):67-73.

Nurdin, E., \& Nugraha, B. (2017). Penangkapan tuna dan cakalang dengan menggunakan alat tangkap pancing ulur (hand line) yang berbasis di pangkalan pendaratan ikan Pondokdadap Sendang Biru, Malang. Bawal Widya Riset Perikanan Tangkap, 2(1):27-33.

Nurdin, E., \& Panggabean, A. S. (2018). Musim penangkapan dan struktur ukuran cakalang (Katsuwonus pelamis Linnaeus, 1758) di sekitar rumpon di Perairan Palabuhanratu. Jurnal Penelitian Perikanan Indonesia, 23(4):299-308.

Orange, C. J. (1961). Spawning of yellowfin tuna and skipjack in the eastern tropical Pacific, as inferred from studies of gonad development. Inter-American Tropical Tuna Commission Bulle- tin, 5(6):457-526.

Pons, M., Kell, L., Rudd, M. B., Cope, J. M., \& Lucena Frédou, F. (2019). Performance of length-based data-limited methods in a multi fleet context: application to small tunas, mackerels, and bonitos in the Atlantic Ocean. ICES Journal of Marine Science, 76(4):960-973.

Prince, J., Victor, S., Kloulchad, V., \& Hordyk, A. (2015). Length based SPR assessment of eleven Indo-Pacific coral reef fish populations in $\mathrm{Pa}$ lau. Fisheries Research, 171:42-58.

Rochman, F., Nugraha, B., \& Wujdi, A. (2015). Pendugaan parameter populasi ikan cakalang (Katsuwonus pelamis, Linnaeus, 1758) di Samudera Hindia Selatan Jawa. BAWAL Widya Riset Perikanan Tangkap, 7(2):77-85.

Restiangsih, Y. H., \& Amri, K. (2019). Aspek biologi dan kebiasaan makanan ikan cakalang (Katsuwonus pelamis) di Laut Flores Dan Sekitarnya. BAWAL Widya Riset Perikanan Tangkap, 10(3):187196.

Satria, F., \& Sadiyah, L. (2017). Possible use of lengthbased spawning potential ratio for skipjack (Katsuwonus pelamis) in Indonesia's Archipelagic Waters. Indonesian Fisheries Research Journal, 23(1):45-53.

Satria, A. I. W., \& Kurnia, R. (2017). Struktur Populasi Ikan Cakalang (Katsuwonus pelamis, Linnaeus 1758): Famili Scombridae: Perairan Pesisir Selatan Laut Jawa. Jurnal Pengelolaan Perikanan Tropis (Journal of Tropical Fisheries Management), 1(1):1-9.

Soares, J. B., Monteiro-Neto, C., da Costa, M. R., Martins, R. R. M., dos Santos Vieira, F. C., de Andrade-Tubino, M. F., \& de Almeida Tubino, R. (2019). Size structure, reproduction, and growth of skipjack tuna (Katsuwonus pelamis) caught by the pole-and-line fleet in the southwest Atlantic. Fisheries Research, 212:136-145.

Stéquert, B., Rodriguez, J. N., Cuisset, B., \& Le Menn, F. (2001). Gonadosomatic index and seasonal variations of plasma sex steroids in skipjack tuna (Katsuwonus pelamis) and yellowfin tuna (Thunnus albacares) from the western Indian Ocean. Aquatic Living Resources, 14(5):313-318.

Syukhriani, S., Nurani, T. W., \& Haluan, J. (2018). Model Konseptual Pengembangan Perikanan Tongkol dan Cakalang yang Didaratkan di Kota Bengkulu. Jurnal Teknologi Perikanan dan Kelautan, 9(1):1-11. 
Tangke, U., \& Deni, S. (2013). Pemetaan daerah penangkapan ikan madidihang (Thunnus albacares) dan ikan cakalang (Katsuwonus pelamis) di Perairan Maluku Utara. Agrikan: Jurnal Agribisnis Perikanan, 6:1-17.

Winarso, B. (2005). Analisis Manajemen "Waktu" pada Usaha Penangkapan Ikan Tuna/Cakalang dengan Sistem Rumpon di Kawasan Timur Perairan Indonesia. Jurnal Ilmiah Binaniaga, 1(01):27-38.

Wujdi, A., Setyadji, B., \& Nugroho, S. C. (2017). Identifikasi struktur stok ikan cakalang (Katsuwonus pelamis, Linnaeus, 1758) di Samudra Hindia (WPP NRI 573) menggunakan analisis bentuk otolith. Jurnal Penelitian Perikanan Indonesia, 23(2):77-88.
Yonvitner, Kurnia, R., \& Boer, M. (2021a). Length Based-Spawning Potential Ratio (LB-SPR), on exploited demersal stock (Priachantus tayenus) in small scale fisheries, Sunda Strait. IOP Conference Series: Earth and Environmental Science, 744(1):012103.

Yonvitner, Boer, M., \& Kurnia, R. (2021b). Length based data of Nemipterus japonicus to spawning potential ratio (SPR) estimation on small scale fisheries (SSF) management in Sunda Strait. IOP Conference Series: Earth and Environmental Science, 674(1):012002.

Zedta, R. R., Rintar, P. A., \& Novianto, D. N. (2018). Estimasi parameter populasi ikan cakalang (Katsuwonus pelamis, Linnaeus, 1758) di Perairan Samudera Hindia. Bawal Widya Riset Perikanan Tangkap, 9(3):163-173. 